Poznań

\title{
Ofensywa partii eurosceptycznych w Wielkiej Brytanii i Niemczech
}

\begin{abstract}
Wstęp
Niniejsze opracowanie prezentuje genezę, pierwszoplanowe postacie oraz założenia programowe i strukturę organizacyjną dwóch partii określających się i odbieranych jako partie eurosceptyczne. Wydaje się, że na przykładzie omawianych tu partii - niemieckiej AfD oraz brytyjskiej UKIP - można wyraźnie określić i poddać szczegółowej analizie zarówno samo zjawisko eurosceptyzmu, jak i zdefiniować zasadnicze problemy formacji, które za swój główny cel obrały odejście (mniej lub bardziej) oraz podważenie istoty Wspólnoty Europejskiej, jako wspólnoty interesów (wspólny rynek, wspólna polityka, wspólna waluta) bezpieczeństwa czy wartości. Zauważalny obecnie eurosceptyzm, jest postrzegany jako wyraz rozczarowania, czy też wręcz buntu przeciw Wspólnocie - wysoce scentralizowanej, arbitralnej, ogromnie zbiurokratyzowanej, niewydolnej, mało elastycznej; ponadto niesłuchającej wyborców, lecz beznamiętnie wdrażającej dyrektywy Brukseli. Tendencja ta nie dotyczy tylko Niemiec czy Wielkiej Brytanii, jest praktycznie obecna w większości krajów-członków Unii Europejskiej, co jasno pokazuje, że coraz powszechniejsze jest przekonanie, że rozwój Unii Europejskiej nie przebiega we właściwym kierunku.

Zarówno AfD, jak i UKIP są reprezentantami krajów, które mają ogromne - jeśli nie największe - znaczenie w Unii Europejskiej. Stąd też rosnące w tych krajach w siłę partie o nastawieniu antyunijnym stanowią realne zagrożenie dla jedności i spoistości organizacji, a nawet istnienia Unii Europejskiej. Poza więc przedstawionymi wcześniej celami tej pracy, omówione będą też pokrótce perspektywy rozwoju sytuacji w dynamicznie zmieniającej się rzeczywistości europejskiej w odniesieniu do narastającego w Europie kryzysu instytucjonalnego Unii Europejskiej.
\end{abstract}

\section{Niemieckie partie protestu}

Rok 2013 był czasem wyborów o dużym politycznym znaczeniu. Obok parlamentarnych z 22 września odbyły się też wybory w trzech najludniejszych krajach związkowych; w Dolnej Saksonii w styczniu, w Bawarii, która ustanowiła swój Landtag 15 września i tydzień później w Hesji. Te najważniejsze do Bundestagu decydują o stworzeniu sprawnego rządu na trudne czasy kryzysu ekonomicznego, określają polityczną przyszłość czołowych polityków i posłów. Na okres kolejnych czterech lat określono priorytety polityki federalnej m.in. wysokość podatków czy plany dotyczące 
udziału Bundeswehry w operacjach wojskowych. Niemiecka zasada demokracji przedstawicielskiej oznacza, że każdy akt wyborczy oznacza dla wyborcy możliwość wzięcia udziału w politycznym procesie decyzyjnym na szczeblu federalnym. 61 milionów obywateli Niemiec uprawnionych do głosowania miało tym samym prawo wybrać tylko takich posłów, którzy reprezentują ich interesy w parlamencie.

Przeprowadzone 22 września 2013 r. wybory do Bundestagu XVIII kadencji miały wymiar historyczny z kilku powodów. Zakończyły się one wyraźnym zwycięstwem partii chadeckich, które uzyskały 41,5\% głosów. Był to przede wszystkim osobisty sukces kanclerz Angeli Merkel, której udało się poprowadzić niemiecką chadecję do najlepszego wyniku od czasu wyborów w 1990 r. Obok chadecji w latach 2013-2017 w Bundestagu zasiadać będą przedstawiciele jeszcze trzech partii: SPD, Die Linke oraz partii Zielonych (patrz Tab. 1). Po ośmiu latach przerwy w Bundestagu ponownie znaleźli się przedstawiciele czterech ${ }^{1}$ partii politycznych, co $\mathrm{w}$ pewnym sensie oznacza odejście od kształtującego się po zjednoczeniu Niemiec, a zwłaszcza po 2005 r., płynnego systemu pięciu partii [fluides Fünfparteiensystem] (Niedermayer, 2008, s. 9-32). Pomiędzy obiema wielkimi partiami oraz pomiędzy trzema mniejszymi zachodzi nadal otwarty, płynny „fluid” stan konkurencji przy wyraźnie wzrastającej segmentaryzacji.

Po dwóch kadencjach rządu Angeli Merkel w roli kanclerza to polityczne status quo napotyka w ostatnim czasie na wyraźny opór ze strony obywateli, którym nie podoba się polityka prowadzona przez istniejące partie. W efekcie powstaje wiele małych ugrupowań politycznych, klasyfikowanych według Oskara Niedermayera jako Kleinstparteien, które nigdy nie były reprezentowane w żadnym Landtagu, Bundestagu czy Parlamencie Europejskim, ale za każdym razem biorą udział w wyborach. Przypisywana jest im specyficzna funkcja suplementarna, która obejmuje swoim działaniem nowe obszary politycznych idei. Artykulacja niezadowolenia utrzymuje elity polityczne w niepewności i przyczynia się niewątpliwie do utrwalenia politycznej tradycji kontroli obywatelskiej w niemieckiej demokracji. Ogółem w okresie od 1946 r. do okresu przed wyborami w 2009 r. na liście Federalnego Komisarza Wyborczego znalazło się 346 partii, które chociaż raz wzięły udział w wyborach do Landtagu. Przed wyborami do Bundestagu w 2013 r. zarejestrowało się 58 partii i ugrupowań, które zapowiedziały w nich swój udział. Liczby te potwierdzają wzrastającą tendencję aktywnej percepcji obywateli Niemiec w życiu politycznym. Republika Federalna Niemiec to kraj, w którym istnieje najwięcej stowarzyszeń, a aktywność publiczna i społeczna ma charakter masowy (7 stowarzyszeń na milion mieszkańców).

$\mathrm{Na}$ fali niezadowolenia $\mathrm{z}$ decyzji rządowych w $2006 \mathrm{r}$. powstało ugrupowanie reprezentujące „digitale Wutbürger” (Plöchinger, 2011) pod przewrotną nazwą Partia Piratów (Piratenpartei), a w roku wyborów do Bundestagu w lutym 2013 sfrustrowani wyborcy CDU założyli Alternatywę dla Niemiec (Alternative für Deutschland - AfD). Szczególnie ta ostatnia wzbudziła dużą konsternację, gdyż żadne sondaże przedwyborcze nie gwarantowały jej więcej niż $2 \%$ głosów. Oba ugrupowania powstały na fali protestu i niezadowolenia z podejmowanych przez koalicję CDU/CSU i FDP (wcześniej z SPD) decyzji politycznych. Wyborcy niezwykle entuzjastycznie przyjęli nowe for-

1 CDU i CSU traktowane są razem. 
macje, a partie bardzo szybko stworzyły swoje oddziały we wszystkich krajach związkowych. Ze względu na szerokie poparcie społeczne stały się poważną alternatywą polityczną nie tylko w wyborach do parlamentu federalnego, ale także perspektywicznymi formacjami w ostrej konkurencji wobec istniejących „starych” partii politycznych. Szczególne zainteresowanie opinii publicznej wzbudziła Alternatywa dla Niemiec, która w sondażach plasowała się za Piratami, a niewiele brakowało, by jej przedstawiciele zasiedli w Bundestagu.

Uwzględniając program i ideologię tych ugrupowań, należy zaliczyć je do typowych partii niszowych. Nie tworzą one obszernych programów, a ograniczają się raczej do krytyki wybranych kwestii i budowania ściśle określonego elektoratu. Piraci doczekali się wielu analiz politologicznych. Pierwsza obszerna monografia autorstwa Henninga Bartelsa (Bartels, 2009) zaprezentowała szczegóły powstania partii i jej rozwój. Pojawiło się też wiele opracowań w pismach politologicznych, pracach studyjnych i analiz publicystów. W roku 2013 specjalistyczne wydawnictwo Springera opublikowało prace zbiorową pod redakcja politologa $\mathrm{z}$ Wolnego Uniwersytetu w Berlinie Oskara Niedermayera, dokonując aktualnej analizy struktur i stan finansów oraz określono grupę docelową tej partii.

AfD ze względu na krótki staż jej istnienia nie doczekała się jeszcze pogłębionych analiz naukowych, ponieważ sama znajduje się w fazie pozycjonowania programowego i wewnątrzpartyjnych przeobrażeń, co skutkuje brakiem jednolitej i konstruktywnej oceny. Prezentowane tu opinie opierają się jedynie na doniesieniach i spekulacjach prasowych oraz wiadomościach prezentowanych na stronach internetowych przez samą partię. Różnorodną i bogatą bazę newsów stanowią dyskusje w sieci.

\section{Europejski eurosceptycyzm}

Kryzys gospodarczy i finansowy pogłębiający od 2008 roku stagnację kolejnych państw UE przyczynił się niewątpliwie do budowania na bazie oddolnych inicjatyw nowych ugrupowań, które staną się alternatywą dla dotychczasowej polityki „,starych” partii, co potwierdza nazwa niemieckiego ugrupowania. Podobne partie powstały też w innych państwach. Greckie partie żądają powrotu drachmy, a Partia Niepodległości Zjednoczonego Królestwa (ang. United Kingdom Independence Party - UKIP) jest postrachem dla brytyjskiego premiera Davida Camerona, fińska partia Finowie (fin. $\mathrm{Pe}$ russuomalaiset) w 2011 roku uzyskała po raz pierwszy w swojej historii najlepszy wynik wyborczy - prawie 19\% poparcia społecznego. Austriacka partia miliardera Franka Stronacha (niem. Team Stronach Neue Werte für Österreich) uzyskała w Karyntii cztery mandaty w 2013 roku i podbija kolejne landy. We Francji tryumfuje Marine le Pen (Front National - FN), a we Włoszech tego samego roku partia Movimento 5 Stelle (Ruch Pięciu Gwiazd) Beppe Grillo uzyskała w wyborach parlamentarnych XVII kadencji 50 mandatów w Senacie i ponad 100 miejsc w Izbie Deputowanych.

W Niemczech, w roku wyborczym 2013 powstała antyeuropejska AfD, z którą sympatyzowało $27 \%$ krytyków euro. Według instytutu badań opinii społecznych TNS Emnid 26\% ankietowanych brało pod uwagę wybór partii sprzeciwiającej się walucie euro i walczącej o rozwiązanie wspólnoty europejskiej. Kryzys gospodarczy w UE 
uaktywnił w Niemczech wiele grup obywateli niezadowolonych z rozwoju gospodarczego i obciążeń finansowych, ponoszonych głównie przez ich kraj. Obecne partie obwiniane są za całe zło, a nowe ugrupowania chcą „,przewietrzyć” niemieckie salony polityczne. Pośród 38 ugrupowań biorących udział we wrześniowych wyborach do Bundestagu były też małe partie, które chciały przejąć władzę metodami satyrycznymi. Istniejąca od 2004 r. partia Die Partei obwinia kanclerz Angelę Merkel za otwarcie muru berlińskiego i chce wprowadzić ,dyktaturę z ludzką twarzą opartą na humanistycznym faszyzmie" (Janik, 2013, s. 75). W programie partii na pierwszym miejscu pojawiły się kwestie gospodarcze i obniżenie wynagrodzeń dla menedżerów. Wraz ze starzejącym się społeczeństwem zamierza zredukować okres obowiązkowej edukacji i obniżyć próg wieku wyborczego. Te dwa postulaty budzą szczególne zadowolenie w szkołach podstawowych i gimnazjach. Cała kampania prowadzona jest w sposób prześmiewczy, w nawiązaniu do rasistowskich teatrzyków popularnych w pierwszej połowie XX w. w USA.

AfD nie jest pierwszą niemiecką partią skupiającą eurosceptyków. Ugrupowania niechętne UE pojawiały się na niemieckiej scenie politycznej wielokrotnie. 21 stycznia 1994 r. z inicjatywy polityka FDP Manfreda Brunnera powołano do życia Sojusz Wolnych Obywateli (niem. Bund Freier Bürger - BFB) w reakcji na podpisany przez RFN traktat z Maastricht. Rok później sojusz wystapił ze skargą do Federalnego Trybunału Konstytucyjnego podważając zgodność traktatu z niemiecką UZ. Pomimo częściowej satysfakcji z ogłoszonego wyroku ${ }^{2}$, partia nie osiagnęła żadnych sukcesów wyborczych. W 2000 r. zgromadzenie federalne BFB podjęło decyzję o rozwiązaniu struktur partii (Decker, Neu, 2007, s. 197-200). Również partia Pro DM/Schill założona cztery lata później w Düsseldorfie podważała sens wprowadzenia euro. Jej założyciel, multimilioner Bolko Hoffmann, prorokował gospodarczy scenariusz pełen upadków przedsiębiorstw, rosnącą inflację i obniżenie standardu życia. Partia miała zahamować wprowadzenie w Niemczech euro. Pozyskanie dla partii w 2003 r. byłego sędziego i hamburskiego senatora spraw wewnętrznym Ronaldo B. Schill nie przyniosły spodziewanych efektów wyborczych. Przeceniono w owym czasie siłę mobilizacyjną elektoratu w kwestii nowej waluty.

Pomimo niepewności i obaw związanych z euro, społeczeństwo niemieckie nie dostrzegało bezpośredniego zagrożenia. Teraz sytuacja jest zgoła odmienna. Niemcy wiedzą, że w 2010 r. ich kraj partycypował kwotą 22 miliardów euro w I pakiecie pomocowym dla Grecji, a już w lutym 2012 r. potrzebny był kolejny. To jeden z powodów, dla których AfD jest pierwszą partią protestu, którą traktuje się poważnie. Chwilowy zastrzyk pieniędzy nie zapewni żadnemu narodowi dobrobytu, a odwlecze jedynie zagrożenie plajtą. Wszystkim państwom europejskim niezbędne są wewnętrzne reformy, kształcenie i edukacja na właściwym poziomie, inwestowanie w nowoczesne badania i innowacyjność, konkurencyjne płace i fleksyjny system socjalny. Słusznie ówczesny włoski prezydent Europejskiego Banku Centralnego Mario Draghi nawoływał „Reformy dla Francji i spółki!” (Er will, 2011).

212 października 1993 r. trybunał uznał zgodność traktatu z konstytucją, ale dołączył do wyroku zastrzeżenie, że Bundestagowi odebrano wiele zadań i uprawnień o znacznej wadze. 
Towarzyszący Europie od początku 2010 roku kryzys w Grecji przyspieszył kryzys polityki europejskiej. Ogólnoeuropejskie kwestie będące obiektem debat politycznych w ramach UE przeniosły się na obszary poszczególnych państw i przybrały wymiar polityki wewnętrznej. Rząd Angeli Merkel/Westerwelle/Rösler odcisnął piętno swojej polityki na europejskich przemianach poprzez stworzenie adekwatnych do nowych wymagań zaleceń. Angela Merkel wraz z prezydentem Francji Nicolasem Sarkozy „zainstalowali" dwa europejskie parasole ochronne, z których państwa pogrążone w kryzysie mogą oczekiwać pomocy finansowej. Uzgodniony pakt fiskalny w sposób zdecydowany przysłużył się do ograniczenia nowego zadłużania się państw eurolandu. Grożąca plajta Grecji została zatrzymana. W przeciwnym razie skutki gospodarcze dotknęłyby wszystkie państwa strefy euro (Woyke, 2013, s. 14). Postrzeganie Niemiec w Europie zmieniło się fundamentalnie. Bez twardej postawy rządu niemieckiego europejskie pakiety ratunkowe długo nie zyskałyby większości parlamentarnej. Na fali zderzania się interesów pojedynczych krajów strefy euro ujawniły się historyczne animozje i egoizm polityczny, który jest zaprzeczeniem integracji europejskiej. Postrzeganie Europy w Niemczech też uległo modyfikacji. Wielu ludzi świata polityki niemieckiej zaczęło wątpić w ideę solidarności europejskiej, a obywatele nie chcą ponosić kosztów nieudolnej polityki fiskalnej państw - członków wspólnoty europejskiej.

Ogólne zadłużenie gospodarki Niemiec za czasów Angeli Merkel wyraźnie wzrosło. Poprzedni kanclerz Gerhard Schröder pozostawił w 2005 roku stan zadłużenia na poziomie $68,5 \%$. Peter Steinbrück (SPD), minister finansów wielkiej koalicji podwyższył dług w czasie kryzysu do poziomu 74,5\%. W 2012 roku zadłużenie Niemiec podniosło się do $81,5 \%$ PKB, a kryteria z Maastricht dopuszczają jedynie $60 \%$ poziom zadłużenia. Na pogarszającą się sytuację ekonomiczną nałożyły się problemy w eurostrefie. Szef AfD Bern Lucke zarzucił rządowi federalnemu kłamstwo, ponieważ określana przez rząd grecka stabilność zadłużenia okazała się w ocenie jej własnych doradców makulaturą. Rząd mając lepszą wiedzę przez trzy lata wbrew radom fachowców „topił” europejskie pieniądze podatników. Pomimo napływu do Grecji 240 miliardów euro, kryzys gospodarczy w Grecji przybrał niszczycielski charakter, a Niemcom przyniósł ogromne straty ekonomiczne (Linke, 2013).

\section{Ludzie partii}

AfD, jak sama pisze o sobie, powstała ,po długiej zimie w pewien wiosenny dzien””. Nazwa partii jest odpowiedzią na używane najczęściej przez polityków niemieckich na czele z Angelą Merkel przymiotnik ,,alternativlos”3 (nie ma alternatywy) w kwestii pomocy finansowej dla Grecji. Słowo miało sugerować jednostronność w procesie decyzyjnym, zamykało dyskusje i otwartość na dodatkowe argumenty. Założyciele nowego ugrupowania postanowili znaleźć alternatywę, udowadniając tym samym, że nie bra-

3 Niezależne jury Towarzystwa Języka Niemieckiego (Gesellschaft für deutsche Sprache - GfdS) pod przewodnictwem germanisty profesora Horsta Dietera Schlossera pośród 1123 nadesłanych propozycji wybrało przymiotnik ,alternativlos” na antysłowo roku 2010 (Unwort des Jahres, 2010). 
kuje alternatywy, a raczej dobrej woli (Göbel, 2011). Partia skierowana jest przeciwko kartelom starych partii, potędze banków i przede wszystkim przeciwko walucie euro z marzeniem o powrocie marki. Nie chce być pozycjonowana na prawo od CDU, a przewodniczący Bernd Lucke potwierdza, że jest jedynie ,partią zdrowego rozsądku”. Partia jak stwierdził „Der Spiegel” „kłusuje” w środowisku mieszczańskim i rozczarowanych wyborcach CDU/CSU i FDP. W dniu powstania AfD (luty 2013) liczyła sześć tysięcy członków, po dwóch miesiącach 7500, obecnie według danych samej partii 75000 (rok 2014). Przeciwnicy pakietu pomocowego dla Grecji działający w CDU nie byli wysłuchani i wręcz ignorowani. Wszyscy oni przelali swoje frustracje i niezadowolenie z polityki chadeków na stronie „Wahlalternative 2013”, gdzie stwierdzili: „Poważnie zaniepokojeni niepożądanymi zmianami politycznymi i gospodarczymi w Niemczech i Unii Europejskiej stworzyliśmy partię „Alternatywa dla Niemiec”. Europejski kryzys zadłużenia i kryzys walutowy przekonał wielu ludzi, że stare partie nie potrafią i nie są gotowe do prowadzenia polityki zrównoważonej, transparentnej, bliskiej ludziom, konstytucyjnej i demokratycznej. Formułujemy alternatywy dla pozornie bezalternatywnej polityki. Tym samym potwierdzamy bez żadnych ograniczeń wolnościowy i demokratyczny porządek Republiki Federalnej Niemiec i pokojowe jednoczenie się Europy w oparciu o ustawę zasadniczą i traktaty rzymskie" (Satzung). Tak przedstawione stanowisko partii, umieszczone na stronie internetowej partii stanowi jednocześnie preambułę statutu, skonstruowanego podczas posiedzenia partii w dniu 14 kwietnia 2013 roku.

Pośród osób popierających program partii znaleźć można utytułowanych przedstawicieli świata nauki, lekarzy, publicystów, prawników, doradców podatkowych i pracowników niemieckiego przemysłu. Gros z nich to byli członkowie CDU. W 5-osobowej radzie naukowej są sami profesorowie uczelni wyższych, w tym dwóch emerytowanych. „Po rewolcie studenckiej lat sześćdziesiątych nadeszło powstanie profesorów, [...] a średnia wieku zarejestrowanych w AfD wynosi poniżej watykańskiego konklawe” (Haste, 2013), stwierdził z uszczypliwością tygodnik „Der Spiegel”. Joachim Starbatty, 73-letni euro fighter z lat 90-tych, z 20-letnim stażem w strukturach CDU, emerytowany profesor Uniwersytetu w Tybindze, były członek prawicowego ugrupowania Bund freier Bürger i kandydat tej partii w eurowyborach w 1994 roku. W szeregach Rady Naukowej AfD aktywnie działa emerytowana profesor Helga Luckenbach, ekonomistka z uniwersytetu w Gießen.

Wśród nowo wybranych rzeczników partii znaleźli się były główny korespondent polityczny dziennika „Die Welt” w Berlinie w latach 2000-2008 Konrad Adam, ostatnio ścisły współpracownik prawicowego tygodnika „Junge Freiheit” oraz jedna „młodsza nadzieja" 50-letni profesor ekonomii politycznej na uniwersytecie w Hamburgu Bernd Lucke. Jest on też jest założycielem i dyrektorem zarządzającym plenum ekonomistów, które zrzesza ponad 300 naukowców w tej dziedzinie. Przez 33 lata był członkiem CDU. Jeszcze rok przed wyborami opowiadał się za ratowaniem strefy euro. Szybko zmienił zdanie, wziął semestralny urlop na uczelni i poświęcił się działalności politycznej. Obok dwóch panów znalazła się też kobieta, matka czwórki dzieci, z wykształcenia chemik dr Frauke Petry. Pośród trzech zastępców są dwaj niezależni dziennikarze; konserwatysta Alexander Gauland i Roland Klaus oraz Patricia Casale, nauczycielka i księgowa zaangażowana w pogłębianie integracji obcokrajowców. 
Właściwymi założycielami partii są Bernd Lucke i Alexander Gauland, którzy wypełnili program treścią. Oni też prezentują partię na zewnątrz, pojawiają się w mediach, udzielają wywiadów. 72-letni Alexander Gauland rozpoczynał swoją karierę przed 50 laty w CDU. W latach osiemdziesiątych za kadencji premiera Waltera Wallmanna (CDU) kierował heską kancelarią stanu. Jak słusznie zauważył tygodnik „Der Spiegel” ,wtedy łatwo uprawiało się politykę, stosunki były przejrzyste. CDU popierała energię atomową, obowiązkową służbę wojskową i tradycyjny model rodzinny, a D-Mark była najmocniejszą walutą kontynentu" (Haste, 2013). Wraz ze zmianą niemieckiej polityki energetycznej (Energiewende) i wydawaniem coraz większych sum na ratowanie euro, bez oporów opuścił szeregi swego ugrupowania. Organizatorem $\mathrm{i}$,sercem” AfD jest nieznany nikomu były policjant z Magdeburga Michael Heendorf. To on organizował zjazdy partii, zapraszał delegatów, tworzył oddziały terenowe. Czyta i weryfikuje wnioski członkowskie w prowizorycznej centrali partii (biuro firmy betonowej należącej do skarbnika partii) z dwoma sekretarkami w małej miejscowości Bad Neuheim w Hesji ${ }^{4}$. Przemierzał tysiące kilometrów po kraju i przybywał wszędzie tam, gdzie tworzyły się nowe krajowe struktury partii, nie pobierając za tę całodobową pracę żadnego wynagrodzenia (Brost, Coen, 2013, s. 4).

Kolejną znamienitością medialną jest publicysta, manager IBM, Hans-Olaf Henkel, były prezydent Federalnego Związku Przemysłu Niemieckiego (BDI) - wielki orędownik wprowadzenia euro. Jego diametralna zmiana poglądów przysporzyła mu niechlubny przydomek „Wendehals” (Krętogłów). Polityków niemieckiej sceny politycznej nazwał fantastami i euro-kłamcami, z którymi polemizuje w swojej książce pod tym samym tytułem Die euro-Lügner. Szczególnie agresywnie atakuje panią kanclerz, ministra finansów Wolfganga Schäubla, poprzedniego ministra finansów Peera Steinbrücka oraz jego sekretarza Jörga Asmussena. Rozlicza też szefa Europejskiego Banku Centralnego Mario Draghi. Chętnie porównuje siebie z byłym berlińskim senatorem finansów Thilo Sarrazinem (SPD), wieszczącym rozpad społeczeństwa niemieckiego pod naporem fali imigrantów, którego książka Niemcy zniszczq się same stała bestsellerem roku 2010. Jego obecność podczas prezentacji książki Henkela w Berlinie potwierdzała ich zbieżne poglądy. Poparcie znalazł także w byłym prezydencie federalnym Christianie Wulffie (CDU), który ostro rozprawił się w swoim przemówieniu z programem „Ratowania euro” przez EBC. Podczas mowy wygłoszonej na spotkaniu laureatów nagrody Nobla z ekonomii w Lindau powiedział „To nieporozumienie mierzyć solidarność gotowością do wspierania finansowego innych, ręczenia za nich i popadania razem z nimi w długi" (Sulik, 2012). Henkel zarzucał również FDP, że wszystkie liberalne zasady „wyrzuciła za burtę”, stojąc za centralizmem w Europie i socjalizacją długów. Henkel ma nadzieję na szybki koniec „euro-tragedii”, a państwa południa jak i niechętna reformom Francja wystapią ze strefy (Jahn, 2013, s. 11).

Partia nie pozyskuje amatorów polityki, ale przyciąga na swoją stronę wielu długoletnich zwolenników CDU jak Hendrik Rottmann, 44-letni oficer Bundeswehry, od 20 lat w CDU, a obecnie piąty na liście AfD w kraju Nadrenii Północnej Westfalii. Ta „dezercja” ze starych ugrupowań dotyczy też FDP. Zasiadający w powiatowym komi-

${ }^{4}$ Centrala partii znajduje się przy ulicy Frankfurter Landstraße 153. 
tecie doradczym w Heidelbergu Matthias Niebel opuścił szeregi FDP na rzecz nowej konkurencji, oskarżając swoją macierzystą partię o zdradę ideałów po tym jak zagłosowała za pakietem ratunkowym dla euro. Wśród prominentnych polityków wolnych demokratów budzi dodatkowe zamieszanie, gdyż jest on kuzynem ministra pomocy rozwojowej Dirka Niebela, wieloletniego sekretarza generalnego liberałów (Amann, Bartsch, Müller, 2013, s. 18). Dwóch na trzech nowych członków AfD nie było nigdy w żadnej partii. Co dziesiąty odszedł z CDU. Każdy nowy wniosek o członkostwo jest weryfikowany pod względem zgodności ze złożoną deklaracją. Kierownictwo partii próbuje dystansować się od prawicowego populizmu i ekstremizmu, ale z drugiej strony głosy tych wyborców są jej bardzo potrzebne w wyborach do Europarlamentu (Priester, 2014, s. 34). Partię popiera też wielu młodych ludzi, który są zatrudnieni w służbie publicznej albo w koncernach i nie mogą się otwarcie przyznawać do swoich politycznych sympatii.

AfD stanowi dla niemieckiej demokracji kuriozum. Tworzą ją znamienici i bez wątpienia demokratycznie myślący politycy, publicyści i ekonomiści, którzy głoszą odejście od euro i stworzenie nowej i mniejszej unii walutowej w europejskich krajach północy. Przyświecające im idee nie są prawicowe ani ekstremistyczne. Przełamali niemoc niemieckiego obozu eurosceptyków do stworzenia konkretnych rozwiązań i zaproponowania swoim zwolennikom wybieralnej alternatywy. „To, że to robia, jest zdobyczą demokracji” (Drieschner, 2013, s. 15) stwierdził dobitnie liberalny tygodnik „Die Zeit”.

\section{Funkcjonowanie i program}

Partia zorganizowana jest z typową niemiecką precyzją i zarządzana energicznie. Krzykacze i awanturnicy, typowi w szeregach nowego ugrupowania trzymani są w ryzach. Kierownictwo ustala program i nie dopuszcza przypadkowych doradców. Nie szuka rozgłosu medialnego, a przedstawiciele prasy nie zawsze są mile widziani. Chociaż nie są to procedury demokratyczne, to efekty imponujące. W krótkim czasie - (pół roku) skutecznie rozbudowała swoje struktury w terenie. Miesięczna składka członkowska wynosi 10 euro, a dla niepracujących 2,5 euro. Członkowie proszeni są o wyższe wpłaty, a wspierający nie tylko sponsorują, ale także uczestniczą bezpłatnie w akcjach plakatowych. Partia otrzymała także wsparcie finansowe od miliardera Augusta von Fincka, współzałożyciela grupy Mövenpick. Jego imperium wspierało kiedyś sporymi sumami FDP. Finansowana jest z darów od osób prywatnych i składek członkowskich. Bliższe dane na temat praktyk finansowych partii nie są znane, ale jej sytuacja finansowa poprawiła się po wyborach w 2013 roku, gdy za osiagnięty wynik uzyskała z kasy państwowej prawie 2 mln euro.

Tabela 1

Wyniki do Bundestagu 2013 (\% głosów drugich)

\begin{tabular}{|l|c|c|c|c|c|c||}
\hline \hline Partia & CDU & SPD & FDP & Die Linke & Piraci & AfD \\
\hline Wyniki & $34,1 \%$ & $25,7 \%$ & $4,8 \%$ & $8,6 \%$ & $2,2 \%$ & $4,7 \%$ \\
\hline
\end{tabular}

Źródło: Dane na oficjalnej stronie Federalnego Komisarza Wyborczego www.bundeswahlleiter.de/de/bundestagswahlen/BTW_Bund_13/ergebnisse/bundesergebnisse. 
Statut zatwierdzony podczas federalnego zjazdu partii wszedł w życie 14 kwietnia 2013 roku i zastąpił pierwotny, założycielski uchwalony 6 lutego 2013 r. Organami partii są: zarząd federalny, federalny zjazd partii i federalny sąd arbitrażowy. Zarząd zgodnie z przepisami ustawowymi RFN nie może składać się w większości z obcokrajowców. Jego członkowie wybierani są co dwa lata (§ 11, pkt 4). Federalny zjazd partii może większością $3 / 4$ odwołać zarząd lub poszczególnych członków (§ 11, pkt 7). Federalny zjazd partii jest najwyższym organem partii, zwoływanym raz do roku. To on dokonuje wyboru zarządu, wyłania członków sądu arbitrażowego i mianuje księgowych i ich zastępców. Decyzje zapadają zwykłą większością głosów, dlatego zjazd jest niezależny od faktycznej liczby przybyłych członków (§ 12, pkt 9). Do zmiany statutu wymagana jest jedynie większość $2 / 3$. Uprawnieni do głosowania są jedynie ci członkowie, którzy nie zalegają ze składką członkowską (§ 12, pkt 1,2). Zjazd przyjmuje też coroczne sprawozdanie z działalności zarządu, przesyłane także elektronicznie wszystkim członkom (§ 12, pkt 16).

Partia odrzuca możliwość członkostwa dla osób, będących wcześniej w szeregach organizacji, sklasyfikowanych przez niemieckie organa bezpieczeństwa jako ekstremistyczne. Wyjątek stanowią osoby, które we wniosku partycypacyjnym poinformowały o tym fakcie partię. Po kontroli pojedynczych przypadków zarząd federalny podejmuje decyzję o przyjęciu członka w szeregi $\operatorname{AfD}(\S 2$, pkt 3$)$. Osoby, które zalegają z opłatą składki przez okres 6 miesięcy i nie zareagowały na dwa upomnienia zostają wykreślone w listy członków (§ 7). Tylko osoby płacące składki mają też prawo do głosowania (§ 12, pkt 2). Dla osób, które nie mogą być lub nie chcą być członkami partii istnieje możliwość działania na zasadach osób wspierających. Płacą oni wtedy połowę należnej składki, otrzymują informacje przeznaczone dla członków i mogą jako goście być dopuszczeni na dni partii bez prawa głosu i składania wniosku (§ 3, pkt 1,2).

Pierwszy program napisany przed zjazdem mieścił się na trzech stronach papieru A4. Żądano w nim stopniowego rozwiązania strefy euro i natychmiastowego zakazu skupu obligacji ,śmieciowych” przez EBC oraz urealnienia dochodów brukselskich urzędników. Program wyborczy został uchwalony w tym samym dniu co statut, podczas założycielskiego dnia zjazdu partii. Obejmuje osiem działów, które podejmują kwestie europejskiej polityki walutowej, energetycznej i integracyjnej oraz kształcenia, zaopatrzenia emerytalnego, finansów państwa, w tym podatków. Główny nacisk położono na politykę wewnętrzną Niemiec i sprawy socjalne. Za najważniejsze wyzwanie AfD uważa powstrzymanie przyjętego przez drugi gabinet koalicji CDU/CSU i FDP w 2009 r. programu rezygnacji z energii elektrycznej pochodzącej z elektrowni atomowych i reformy uchwalonej 1 kwietnia $2000 \mathrm{r}$. ustawy o energiach odnawialnych (Gesetz für den Vorrang erneuerbarer Energien - w skrócie EEG) (szerzej zob. Janicka, 2013). Jednym z filarów trwałości zdobyczy demokracji niemieckiej i państwa prawa jest zdaniem AfD zasada odpowiedzialności, solidarności i transparentności, w ramach której wolnościowy i demokratyczny porządek prawny zapewnia wolność wypowiedzi i otartą na dyskusję kulturę słowa. W sprzeciwie wobec tendencji zastraszania ludzi o odmiennych poglądach $i$ alienowania ich ze społeczeństwa partia proponuje wprowadzenie w Niemczech i Europie reguł demokracji bezpośredniej, wzorowanej na kulturze szwajcarskiej. Gros prezentowanych postulatów powielono w propozycjach programu europejskiego (Politische, 2014). 
W uchwalonym 22 marca 2014 roku programie wyborczym do Parlamentu Europejskiego „Mut zu Deutschland” (Odwaga dla Niemiec) partia żąda „geordnete Auflösung” (,uporządkowanego" rozwiązania) strefy euro, a samym Niemcom proponuje jej stopniowe opuszczanie. Sprzeciwia się centralizmowi unijnemu na rzecz większej odpowiedzialności i partycypacji obywateli wszystkich regionów, gmin i krajów w podejmowaniu decyzji strategicznych dla mieszkańców UE. Konsekwencją tych propozycji jest możliwość stosowania prawa weta (także weta obywatelskiego) w parlamentach narodowych wobec aktów ustawodawczych, uchwalanych przez organy unijne. Żąda także ukrócenia przywilejów dla urzędników unijnych, zmniejszenia ich liczby o połowę, w tym także komisarzy i likwidacji dwóch siedzib parlamentu europejskiego. Opowiada się za wspólną unijną polityką zagraniczną i bezpieczeństwa, popierając tym samym ideę wspólnych interesów europejskich.

AfD podkreśla konieczność sprawiedliwego wynagrodzenia dla pracowników - obcokrajowców. Powinni oni podlegać tym samym regulacjom prawnym co rodacy, a weryfikacja pracownicza oparta na kryterium kompetencji daje taką gwarancję. W wyraźnym kontraście do pomówień medialnych o konotacje partii ze skrajną prawicą opowiada się za krajem otwartym na cudzoziemców, akceptującym prawo do wyboru miejsca zamieszkania w ramach europejskiej swobody przepływu pracowników (Das Program, 2014).

\section{Specyfika systemu partyjnego Wielkiej Brytanii}

Współczesny system partyjny Wielkiej Brytanii ma wielowiekowe tradycje, chociaż stronnictwa przypominające te dzisiejsze pojawiły się dopiero pod koniec XVII wieku. Chodzi tu o wyrażających sprzeciw wobec absolutyzmu królów z dynastii Stuartów wigów oraz reprezentujących interesy ziemian i przedstawicieli katolickiego Kościoła, popierających monarchię torysów (Dańda, 2010, s. 362). To one dały podwaliny pod kształt obecnych politycznych ugrupowań tego państwa - wigowie ewaluowali w stronnictwo liberałów, natomiast torysi - w prawicową Partię Konserwatywną. XIX-wieczne reformy prawa wyborczego doprowadziły ostatecznie do powstania dużej ilości obozów z Partią Pracy na czele (Dańda, 2010, s. 362).

Dziś system brytyjski, choć uznawany za dwupartyjny, nie do końca takim pozostaje. W parlamencie przedstawicieli swoich interesów mają bowiem, oprócz wyborców dwóch największych partii, mniejsze grupy obywateli, skoncentrowanych zazwyczaj, choć nie zawsze, na danym obszarze geograficznym (Antoszewski, Herbut, 2001, s. 183). I tak, swoją reprezentację posiadają stronnictwa szkockie, walijskie oraz północnoirlandzkie. Cechą charakterystyczną na brytyjskiej scenie politycznej jest również zjawisko „regionalizacji systemu partyjnego”. Po przestudiowaniu rozkładu głosów dla dominujących partii na danych obszarach, okazuje się, że mają one geograficznie nierównomiernie umiejscowiony elektorat - „Partia Konserwatywna dominuje raczej na południu kraju, zaś Partia Pracy może liczyć przede wszystkim na elektorat skupiony w północnych hrabstwach" (Antoszewski, Herbut, 2001, s. 184). 


\section{Partie polityczne w brytyjskiej przestrzeni politycznej i parlamentarnej}

Struktura współczesnego życia politycznego Wielkiej Brytanii jest zatem oparta o istnienie dwóch dominujących ugrupowań (Partia Konserwatywna i Partia Pracy), jednego mniejszego (Liberalni Demokraci), a także szeregu partii z reprezentacją parlamentarną oraz bez niej. Partia Konserwatywna, powstała w 1832 roku, z przekształcenia ugrupowania torysów, uznawana jest za partię, która wielokrotnie dzierżąc stery rządów w XIX i XX w., odniosła największe sukcesy na brytyjskiej scenie politycznej (wystarczy wymienić w tym kontekście nazwiska: Roberta Peelego, Benjamina Disraeliego, Winstona Churchilla czy Margaret Thatcher). Konserwatyści w swoim programie odwołują się do takich wartości jak: wolność jednostki, rządy prawa, minimalna rola państwa $\mathrm{w}$ gospodarce, wspieranie własności prywatnej, niskie podatki dochodowe (Dańda, 2010, s. 367). Konserwatyści popierają członkostwo Wielkiej Brytanii w Unii Europejskiej, z tym, że są zdecydowanie przeciwni przenoszenia suwerenności narodów na rzecz wzmocnienia unijnych struktur.

Założona w 1900 roku Partia Pracy swoją mocną pozycję ugruntowała w latach 90. $\mathrm{XX}$ wieku. Wtedy to zdecydowała się odstapić od tradycyjnego programu politycznego na rzecz tzw. Programu New Labour stworzonego przez ówczesnego lidera - Tony'ego Blaira. Dzięki temu przeszła transformację z partii lewicowej w centrolewicową, co poskutkowało falą poparcia ze strony osób do tej pory z nią nie sympatyzujących. Po tej swoistej „,metamorfozie” laburzyści ,zaakceptowali wolny rynek jako właściwe środowisko rozwoju gospodarczego państwa, zmniejszyli swoje uzależnienie od związków zawodowych [...] oraz zaproponowali reformę ustroju politycznego Zjednoczonego Królestwa" (Dańda, 2010, s. 368). Partia Pracy stanowczo popiera brytyjskie członkostwo w UE, a także, w przeciwieństwie do Partii Konserwatywnej, zgadza się na przekazanie większej ilości kompetencji unijnym organom.

„Budowa i obrona wolnego, sprawiedliwego i egalitarnego społeczeństwa opartego na wartościach takich jak: wolność, sprawiedliwość i współpraca w ramach społeczności lokalnej i ogólnopaństwowej” to z kolei założenia statutu partii Liberalnych Demokratów (Dańda, 2010, s. 369). Ugrupowanie to kontynuuje tradycje istniejącej od końca XVII wieku Partii Liberalnej. W kwestii stosunku do struktur unijnych, popiera brytyjskie w nich członkostwo.

Kolejne partie będące uzupełnieniem sceny politycznej, to między innymi Demokratyczna Partia Unionistyczna, czyli drugie, obok Ulsterskiej Partii Unionistycznej, ugrupowanie lojalistów z terenu Irlandii Północnej. Na uwagę zasługuje także Szkocka Partia Narodowa, która głównym postulatem uczyniła uzyskanie przez Szkocję pełnej niepodległości i równocześnie odrębnego członkostwa w UE. W kwestiach gospodarczych i społecznych jest ugrupowaniem umiarkowanym, centrolewicowym (Dańda, 2010, s. 370).

Na brytyjskiej scenie politycznej istnieje jeszcze kilka innych ugrupowań z bardziej lub mniej widoczną reprezentacją. Ze względu na swoje polityczne sukcesy i medialne zainteresowanie godna uwagi jest Partia Niepodległości Zjednoczonego Królestwa (UKIP). Powstała ona na bazie formacji politycznej mającej swoje początki w roku 1991, powstałej w wyniku zdecydowanej dezaprobaty wobec Traktatu z Maastricht i przekształconej dwa lata później przez Alana Skeda w pełnowymiarową partię poli- 
tyczną. Celem strategicznym UKIP jest wyprowadzenie Wielkiej Brytanii z Unii Europejskiej. Od początku swojego istnienia partia ta działa na marginesie sceny politycznej. Rok 2001 był rokiem przełomowym, bo choć był to rok nieudanych wyborów parlamentarnych, to w wyborach do Parlamentu Europejskiego UKIP zajął trzecie miejsce, podobnie zresztąjak w roku 2004. W roku 2006 Nigel Farage zostaje wybrany na lidera UKIP. Jego reputacja jako lidera partii, była wielokrotnie podważana, gdyż uważano, iż: „Nigel Farage gra na najniższych instynktach ludzi, bazując na strachu przed obcymi. Członkowie zaś jego partii, jak i on sam odpowiadają programowo na wołania anarchistów, neurotyków, ludzi problematycznych, nieprzyjaznym obcokrajowcom" (Scheuermann, 2014a, s. 92). W roku 2009 jego partia zajmuje drugie miejsce w wyborach europejskich. Warto zwrócić uwage, że w wyborach do Izy Gmin z 6 maja 2010 roku stronnictwo to nie zdobyło ani jednego mandatu. Fakt ten potwierdza intensywność działań na rzecz popularyzacji swojego programu i tempa, w jakim partia zdobyła poparcie w okresie czterech lat, do wyborów europarlamentarnych z 2014 roku.

Tabela 2

Wyniki wyborów do brytyjskiej Izby Gmin z 6 maja 2010 roku (wyniki 6 partii wg osiągniętych najlepszych wyników wyborów)

\begin{tabular}{|l|c|c|c|c|c|c||}
\hline \hline Partia & CP & LP & LD & UKIP & BNP & SNP \\
\hline Wyniki & $36,1 \%$ & $29 \%$ & $23 \%$ & $3,1 \%$ & $1,9 \%$ & $1,7 \%$ \\
\hline
\end{tabular}

Źródło: Election Resources on The Internet: Parliamentary Elections in the U.K. - House of Commons Results, www.electionresources.org/uk/.

Wyniki wyborów do Izby Gmin idealnie oddają charakter brytyjskiego systemu parlamentarnego, pokazują potęgę trzech największych ugrupowań i marginalne znaczenie reszty stronnictw. Jak się jednak okazuje, nawet niewielkie teoretycznie partie, mogą zmienić historię polityki państwa na arenie międzynarodowej.

Wyniki wyborów do Parlamentu Europejskiego doskonale ilustrują taką właśnie zmianę.

Tabela 3

Wyniki wyborów do Parlamentu Europejskiego w Wielkiej Brytanii w 2014 roku

\begin{tabular}{|l|c|c|c|c|c|c||}
\hline \hline Partia & UKIP & LP & CP & GP & LDP & SNP \\
\hline Wyniki & $26,77 \%$ & $24,74 \%$ & $23,31 \%$ & $7,67 \%$ & $6,69 \%$ & $2,4 \%$ \\
\hline
\end{tabular}

Źródło: Parlament Europejski, Wyniki wyborów do Parlamentu Europejskiego w 2014 r., www.wyniki-wybory2014.eu.

Komentując zwycięstwo UKIP Maciej Czarnecki na łamach „Gazety Wyborczej” napisał: „Zwycięstwo UKIP to mocny sygnał ostrzegawczy. Zwłaszcza, że populiści wypadli też nadspodziewanie dobrze w wyborach lokalnych, które odbywały się wraz $\mathrm{z}$ europejskimi. Mocna pozycja w terenie może procentować $\mathrm{w}$ wyborach parlamentarnych w 2015 r., w których okręgi są jednomandatowe. Sukces UKIP pokazuje rozczarowanie Brytyjczyków ugrupowaniami głównego nurtu i ich niechęć do imigrantów. Oczywiście politycy od prawa do lewa pocieszają się, że «to tylko eurowybory», które 
wykorzystuje się do tego, by dać rządzącym prztyczka w nos. Bądź co bądź, w poprzednich z 2009 r. populiści Farage'a zgarnęli 13 mandatów (16,6 proc. głosów), a rok później w batalii o Westminster ani jednego" (Czarnecki, 2014). Z pewnością jednak zwycięstwo partii Farage'a można określić jako historyczny sukces, gdyż od dziesięcioleci w Wielkiej Brytanii wygrywała albo Partia Pracy, albo Konserwatyści.

\section{„Dumny dom eurosceptyzmu”, czyli przyczyny rosnącej popularności UKIP}

Gospodarcze i społeczne przyczyny eurosceptyzmu pojawiły się w wielu europejskich państwach, w tym również w Wielkiej Brytanii pod koniec ubiegłego dziesięciolecia. Kryzys strefy euro pokazał jak bardzo integracja gospodarczo-walutowa potrzebuje wzmocnienia. Równocześnie podczas kolejnych szczytów unijnych widać było, jak chłodno i zdystansowanie Brytyjczycy podchodzą do jakichkolwiek pomysłów zacieśnienia europejskiej integracji. Sięgający 2008 roku kryzys finansowy podzielił Europę na zwolenników organizacji i kalkulujących sceptyków. Stosowane przez Unię Europejską narzędzia ekonomiczne nie pomogły w uchronieniu wspólnoty przed załamaniem, co wpłynęło na większość państw członkowskich.

Dane Brytyjskiego Urzędu Statystycznego nie pozostawiają żadnych złudzeń. W przypadku tego państwa bardziej kalkuluje się funkcjonowanie poza Wspólnota, niż działanie w jej ramach. W 2010 roku korporacje finansowe zapewniły gospodarce Wielkiej Brytanii 123 mld funtów wartości dodanej, a w 2011 roku 50 proc. swego eksportu kierowała poza UE. Jak oszacowała Komisja Europejska, Wielka Brytania należy do tzw. grupy płatników netto budżetu unijnego i dokłada rocznie „na czysto” ok. 4-5 mld euro (Gmurczyk, 2014). Nie dziwią zatem chłodne odczucia mieszkańców Wysp wobec wspólnoty.

Idealnym podsumowaniem przyczyn eurosceptyzmu brytyjskiego może być wypowiedź Michael'a White'a, reportera i zagranicznego korespondenta „The Guardian”, który w styczniu 2012 roku napisał: „Brytyjczycy nie mają monopolu na eurosceptycyzm, ale podejrzenia wobec projektu europejskiego istnieją w brytyjskim nurcie dłużej, niż gdziekolwiek indziej. Było to widoczne już w pełnych nieufności wspólnych dla obu rządów - laburzystów i torysów - pierwszych drżących krokach w kierunku Unii Europejskiej. [...] Dla wielu kryzys euro, który następnie rozszerzył się na kryzys bankowy lat 2007-2009 służy tylko do udowodnienia arogancji i głupoty przywódców europejskich. Eurosceptycy byli szczęśliwi, mogąc zrzucić winę za porażki na przepisy państwowe, a nie na rynkową chciwość i nieodpowiedzialności bankierów, którzy kusili obietnicą łatwych pieniędzy w przeciwieństwie do srogiego języka brukselskich biurokratów. To była idealna burza, dekady tworzenia, aż niebo Unii Europejskiej pociemniało i grzmot uderzał coraz głośniej. Do teraz, już od lat dziewięćdziesiątych eurooptymizm ustępował miejsca eurosceptycyzmowi na całym kontynencie. Od Finlandii i Austrii do bezrobotnych młodych pracowników próbujących opuścić Hiszpanię i Portugalię. Nawet w lojalnych państwach założycielskich - Holandii, Francji i Niemczech - eurosceptycyzm i ksenofobiczne partie znów zaczęły rosnąć w siłę. Eurosceptycyzm okazał się być jednym z bardziej udanych brytyjskich produktów eksportowanych przez kanał" (White, 2014). 
W takiej właśnie atmosferze ekonomicznych wyliczeń i ogólnego niezadowolenia z działań wspólnoty, w siłę zaczęła rosnąć coraz popularniejsza największa brytyjska eurosceptyczna grupa polityczna, Partia Niepodległości Zjednoczonego Królestwa.

\section{Program polityczny i funkcjonowanie UKIP}

Głównym długofalowym celem Partii Niepodległości jest wyjście Wielkiej Brytanii z Unii Europejskiej. Drogą do realizacji tego nadrzędnego celu, ma być szereg celów pośrednich zawartych w programie partii w oparciu także o jasno określone wartości.

Oficjalna strona internetowa jest najlepszym źródłem informacji na temat idei wyznawanych przez członków partii. Według nich Wielka Brytania może stać się znów demokratycznym, samostanowiącym państwem, a „cel ten można osiagnąć jedynie przez stopniowe wyprowadzanie narodu z Unii Europejskiej i umacnianie suwerenności parlamentu" (What, 2014). Partia głosi również hasło gotowości państwa do bycia niezależnym tworem, który może prowadzić wymianę gospodarczą i budować pozytywne relacje z całym światem „na własną rękę”. Co ciekawe, jednym z jej postulatów jest też „odzyskanie kontroli na granicami państwa”, rozumiane jako przyjmowanie obcokrajowców, którzy mogą przyczynić się do wzrostu kraju, a jednocześnie kontrolowaniu liczby osób przybywających do Wielkiej Brytanii bez konkretnych umiejętności, które „byłyby korzyścią dla narodu”. Program polityczny, oprócz ogólnych postulatów, składa się też z konkretniejszych idei i podzielony został na kilka bloków.

Treść bloku pierwszego - „Przywrócenie władzy Wielkiej Brytanii” cytując tekst ze strony internetowej streścić można w jednym zdaniu ,głos na UKIP to głos za opuszczeniem Unii Europejskiej i odzyskaniem władzy nad życiem kraju" (What, 2014). Mieszczą się tutaj dwa główne postulaty: wolny handel z europejskimi sąsiadami, ale bez politycznej unii oraz prawa do referendów krajowych i lokalnych oraz respektowanie ich postanowień. Blok drugi - „Ochrona naszych granic” to postulat odzyskania kontroli nad granicami Wielkiej Brytanii i szeroko rozumiana dość restrykcyjna polityka imigracyjna. Kolejna grupa postulatów „Odbudowa dobrobytu” zakłada ochronę rynku pracy, preferencyjne warunki dostępu do rynku pracy dla Brytyjczyków, przyjazny system fiskalny oraz pozyskania i wykorzystania źródeł energii. Blok czwarty odnosi się do „Ochrony przed przestępczością” i zakłada między innymi zwiększenie finansowania policji, kontrole graniczne, ekstradycje dla przestępców spoza UK i ograniczenie praw więźniów. Grupa piąta - „Opieka i wsparcie dla wszystkich” zapowiada: ułatwienie dostępu do lekarzy, rozwój szkolnictwa i wsparcia socjalnego dla określonych grup społecznych. Ostatni - szósty blok - „Wolność słowa i demokracja” zakłada brak wymogu politycznej poprawności i pełną wolność wypowiedzi oraz edukację patriotyczną (What, 2014).

Partia Niepodległości działa na zasadzie masowego członkostwa. Aby dołączyć do ugrupowania wystarczy zarejestrować się na stronie internetowej i wpłacić odpowiednią sumę pieniędzy. W funkcjonowaniu stronnictwa pomagaja, jak w przypadku większości partii, wolontariusze, którzy również mogą się zgłaszać za pomocą strony. Witryna partii daje także możliwość udzielenia jej finansowego wsparcia oraz wyszukania informacji na temat jej liderów. 


\section{Nigel Farage - charyzmatyczny przywódca czy maskotka mediów?}

I choć na stronie UKIP „kluczowych postaci” wymieniono kilka, to nie ma wątpliwości, że aktualnie lider jest jeden. Nigel Farage, bo o nim mowa, po ukończeniu prywatnej szkoły nie poszedł na studia. Został maklerem w londyńskim City. Od 1999 roku był członkiem Parlamentu Europejskiego jako reprezentant południowo-wschodniej Anglii. Jak podaje witryna partii „swoje wieloletnie doświadczenie wykorzystuje teraz w kraju do zwiększenia świadomości na temat działań Unii Europejskiej” (About). W listopadzie 2010 roku został ponownie wybrany na przywódcę partii. Przez wrogów politycznych nazywany Mr Kettle, czyli Czajnik. Gazety w Wielkiej Brytanii i całej Europie zarzucają mu fałsz i korzystanie z unijnych pieniędzy, ukryte pod populistycznymi hasłami o konieczności wyjścia ze struktur wspólnot. W 2009 r. dzięki publikacji w „The Guardian” Brytyjczycy dowiedzieli się, że Farage pobrał dwa miliony funtów z budżetu Unii, by pokryć koszty utrzymania biura i podróży (Rybarczyk, 2014, s. 58-60). Nie byłoby w tym zapewne niczego zaskakującego, gdyby nie jawna nienawiść Farage'a do struktur europejskiej wspólnoty. Brytyjskie pisma zajęły się także oceną zagrożenia, jakim stała się UKIP $i$ jej przywódca dla innych partii w wyborach do brytyjskiego parlamentu - szczególnie dla Partii Pracy i konserwatystów w 2015 roku. Punktem wyjścia były korzystne dla UKIP sondaże w przeddzień wyborów do Parlamentu Europejskiego. Tygodnik „The Economist” w wydaniu z 17 maja 2014 roku podkreślał, że laburzyści mogą mieć problemy z wygraną (Taking).

Możliwy scenariusz wyborczy opisywano w sposób jednoznaczny: „Mówiąc o Wielkiej Brytanii, z całym jej pełnym eurosceptycznych oczekiwań nastawieniem, Partia Laburzystów i tak powinna być na drugim miejscu z nieznaczną stratą lub nawet zdecydowanie wygrać. Trzęsienie ziemi, jakie już dawno obiecał przywódca polityczny UKIP, Nigel Farage, jest bliskie. Pytanie o wybory powszechne w przyszłym roku dotyczy tego, jak torysi, główna ofiara powstania UKIP, odpowiedzą na jej działania". „The Economist” porównywał też sytuację partii politycznych w wyborach z 2014 roku i tych, które nastąpią za rok: „Szanując kredyt zaufania, jaki otrzymali od swoich wyborców, torysi będą prowadzić powściagliwą kampanię wyborczą. Gardząc konkurencją z pełnym skandalicznych, jak na przykład zamknięcie granic i zmniejszanie podatków, gwarancji programem UKIP, premier Cameron ponawia tylko obietnicę referendum i żałuje, że imigracja to problem dla wielu brytyjskich wyborców. [...] UKIP nie przetrwa przyszłej kampanii wyborczej tak łatwo, jak tej europejskiej, która sama w sobie jest drwiną" (Taking).

Prasa europejska zainteresowała się postacią Farage'a na długo przed wyborami do Europarlamentu. W styczniu 2013 roku, niemiecki publicysta Christoph Scheuermann pisał na stronie internetowej tygodnika „Der Spiegel”: „Od miesięcy jego propozycje spychają w cień rząd, dzięki czemu gwałtownie rośnie poparcie dla jego partii wśród wyborców. Najnowsze badania pokazują, że za UKIP opowiada się $15 \%$ ankietowanych, co czyni z niej trzecią najważniejszą siłę polityczną w kraju, po konserwatystach i Partii Pracy. Nikt nie wierzy, że UKIP może wygrać w wyborach do niższej izby parlamentu, po części dlatego, że brytyjski system stawia małe partie w niekorzystnej sytuacji. Sondaże są jednak wystarczające, by zachwiać pozycją premiera Camerona i jego strategów" (Scheuermann, 2014b). 
O UKIP równie chętnie pisze polska prasa. W styczniu 2013 roku polski tygodnik opinii „Polityka” pisał: „Nigel Farage promienieje młodzieńczą werwą. Jest liderem Partii Niepodległości Zjednoczonego Królestwa (UKIP), ugrupowania, które jeszcze trzy lata temu mieściło się na kanapie, a dziś szantażuje szefa rządu Jej Królewskiej Mości, żądając referendum w sprawie wyjścia Wielkiej Brytanii z Unii Europejskiej. Cały sekret sukcesu partii Farage'a polega na prostocie przekazu, możliwej dzięki temu, że w imieniu UKIP wypowiada się w zasadzie tylko jej szef: kraj schodzi na psy, imigracja i małżeństwa gejowskie zrobią z nas wkrótce metroseksualnych kosmopolitów, a jedynym rozwiązaniem tych wszystkich problemów jest rychłe wystapienie z Unii Europejskiej. Farage dobiera tematy w zależności od chwili. Gdy pod koniec 2012 r. Cameron zapowiedział, że jego partia gotowa jest poprzeć wprowadzenie małżeństw homoseksualnych, następnego dnia okazało się, że sprzeciw wobec takich związków jest fundamentem programu UKIP. Farage już zapowiedział, że chce z tej sprawy uczynić temat przewodni kampanii w 2015 r. Po dwóch tygodniach ponad 30 posłów Partii Konserwatywnej oświadczyło, że stoi po jego stronie" (Wójcik, 2013).

Opinii podobnych do tej jest mnóstwo w większości liczących się polityczno-społecznych pism europejskich, od Anglii, przez Niemcy, do Polski. Stawiają one pod znakiem zapytania wiarygodność programu Partii Niepodległości, a z samego Farage’a robią populistę. ,Lider UKIP od roku jest wręcz maskotką brytyjskich mediów. Podnosi wyniki oglądalności, więc jest chętnie zapraszany. Mówi dowcipnie i zrozumiale o trudnych sprawach. Wali prosto z mostu. [...] Farage jak inni populiści opowiada ludziom to, co chcieliby usłyszeć, a czego nie mówią politycy głównego nurtu. Pracoholik, wiecznie dokądś goni i z kimś się spotyka. Potrafi udzielać wywiadów po 20 godzin dziennie" (Rybarczyk, 2014, s. 58-60).

Trudno dokonać jednoznacznej oceny przywódcy UKIP. Na pewno nie można mu odmówić zręczności i oddziaływania poprzez media na szerokie rzesze wyborców. $\mathrm{Z}$ pewnością jest osobą medialną, dobrze czującą się w takim otoczeniu. Przyczyną ogromnego zainteresowania jego osobą są jego wysoce kontrowersyjne opinie, wzbudzające ogromne emocje. Takim przykładem może być np. porównywanie Unii Europejskiej do Związku Radzieckiego, podziw dla Władimira Putina jako zręcznego polityka, czy ostre, bezpardonowe wypowiedzi na temat najważniejszych polityków europejskich czy unijnych. Można przypuszczać, że wypowiedzi te to świadomie przemyślana strategia zdobywania popularności oraz zwolenników, a przede wszystkim zainteresowana mediów. Jest dobrym mówca, ale potrafi też z ludźmi rozmawiać i ich słuchać, wyciagać wnioski. Z drugiej jednak strony zarzuca mu się populizm, proste, jednostronne myślenie, które może jednak nie wytrzymać konfrontacji ze skomplikowana, pełną rozmaitych powiązań rzeczywistością. Zręcznie odpycha od siebie opinię, iż prezentowane przez niego poglądy mają charakter dyskryminacyjny, choć finansowana przez niego np. kampania billboardowa zamiast przekonywać do gościnności wobec imigrantów ma zgoła inne, wręcz wrogie wobec nich oblicze. Jego poglądy w pewien sposób łamią dotychczasowe standardy myślowe Brytyjczyków, których kraj oparty jest - jako kraj o dojrzałej demokracji - na poszanowaniu praw człowieka, tolerancji walczącej z dyskryminacją. Przekaz, jaki prezentuje UKIP trafia jednak - na fali rozszerzającego się eurosceptyzmu - do coraz szerszej rzeszy odbiorców na co 
z pewnością ma wpływ zarówno charyzma jego lidera jak i będąca tego pochodną popularność medialna.

\section{Podsumowanie}

Partie eurosceptyczne swoją nagłą popularność zawdzięczają kryzysowi gospodarczemu strefy euro, który rozpoczął się w ubiegłym dziesięcioleciu. Szczególnie silny wzrost poparcia odnotowały te funkcjonujacce na terenie państw bogatych i wnoszących dużo do gospodarki wspólnoty. Idealnym przykładem są tutaj Niemcy oraz Wielka Brytania. I choć w obu tych krajach w ostatnim czasie partie antyeuropejskie przeżyły prawdziwy rozkwit, to ich program znacząco się różni. Najłatwiej różnicę między sytuacją na scenie politycznej pokazać odwołując się do największych ich partii eurosceptycznych. Działająca w Niemczech AfD nie zakłada silnej negacji idei leżących u podstaw wspólnoty. Skupia się za to na finansach państwa, które przez kryzys na południu Europy i wynikającą z członkostwa w UE konieczność ich wsparcia, wydaje duże sumy na cele, dla zwykłego niemieckiego obywatela nieuzasadnione. Brytyjska Partia Niepodległości z kolei krytykuje wspólnotę i wszelkie jej założenia. Dąży do tego, by państwo opuściło jej struktury i samo kształtowało własną politykę gospodarczą oraz społeczną.

Co dla Europy oznacza popularność nowo powstałych partii? Podstawowy, namacalny skutek otrzymaliśmy w maju tego roku podczas wyborów do Parlamentu Europejskiego. „To będzie już inna Unia Europejska”, pisał tuż po nich portal niezależna.pl (To będzie, 2014). We Francji z wynikiem 24,86\% wygrał Front Narodowy, W Wielkiej Brytanii zwyciężyła, dążąca do wyjścia państwa ze struktur UKIP. W Niemczech, istniejąca od zaledwie roku AfD zdobyła 7,1\% głosów. Takie rozłożenie poparcia jest najlepszym dowodem na to, że faktycznie Europejczycy są skłonni zrezygnować z rozwiązań, jakie daje unia na rzecz samostanowienia państw.

Tuż po wyborach do PE Marek Bankowicz, politolog, a także ekspert ds. systemów politycznych i wyborczych z Uniwersytetu Jagiellońskiego tłumaczył sukces ugrupowań nacjonalistycznych i eurosceptycznych, mówiąc w wywiadzie dla portalu Gazeta.pl: „Znacznej części wyborców europejskich nie odpowiada model integracji lansowany przez Brukselę. Uważa się, że te procesy integracyjne idą za daleko, że Bruksela zawłaszcza dla siebie zbyt dużo kompetencji i zajmuje się nie tylko sprawami gospodarczymi, ale też uzurpuje sobie prawo do zastępowania państw narodowych w sprawach politycznych. Wielu wyborcom się to nie podoba. Ten proces idzie według nich za szybko, odgórnie. [...] Nie ma poczucia tożsamości między społeczeństwami a strukturami decyzyjnymi w Brukseli i Strasburgu. Apogeum kryzysu mamy wprawdzie za soba, ale jego przyczyny nie zostały usunięte. Deklaracje o tym, że Unia Europejska jest gwarantem dobrobytu, mają się nijak do rzeczywistości. To napędza te partie, które chcą ,przepędzić Unię” (Beczek, 2014). Pewne jest, że bezprecedensowy sukces w wyborach do PE może wpłynąć na dalszą ekspansję partii eurosceptycznych. Nie ulega wątpliwości, że utrzymujące się chłodne wobec unii odczucia Europejczyków, mogą przełożyć się na zwycięstwa tych ugrupowań w wyborach krajowych. Wyjątkowo dobre wyniki AfD w wyborach landowych 2014 (AfD weszła do parlamentów Brandenburgii 
- 12,2\%, Turyngii - 10,6\% i Saksonii - 9,7\%) (Jendroszczyk, 2014) potwierdzaja jedynie tę tendencję. Na stwierdzenie, czy eurosceptycy zostaną dłużej w politycznych salonach państw jest jeszcze za wcześnie. Trzeba jednak pamiętać, że skoro tak szybko stali się znaczący „głosem” Europy, mogą zagrozić dalszej integracji członków unii, a być może nawet doprowadzą do stopniowego zmniejszania się ich liczby.

\section{Bibliografia}

About Nigel, http://www.ukip.org/about_fnigel, 17.08.2014.

Amann M., Bartsch M., Müller P., Neukirch R., Sauga M. (2013), Der Feind im Innern, „Der Spiegel”, nr 20.

Antoszewski A., Herbut R. (2001), Systemy polityczne współczesnego świata, Wydawnictwo Arche, Gdańsk.

Bartels H. (2009), Die Piratenpartei. Entstehung. Forderungen und Perspektiven der Bewegung, Berlin.

Beczek W., To będzie najbardziej eurosceptyczny Parlament Europejski w historii. Skrajne ugrupowania trzeciq siła w Brukseli? „Ludzie się boja”, Gazeta.pl, http://wiadomosci.gazeta.pl/wiadomosci/1,114871,16037855,To_bedzie_najbardziej_eurosceptyczny_Parlament_Europejski.html, 24.08.2014.

Brost M., Coen A. (2013), Wie wird aus Protest eine Partei?, „Die Zeit” 11.04.2013.

Czarnecki M., Zwycięstwo eurosceptyków z UKIP w Wielkiej Brytanii to mocny sygnat ostrzegawczy, http://wyborcza.pl/1,75477,16035217,Zwyciestwo_eurosceptykow_z_UKIP_w_Wielkiej_Brytanii.html, 16.08.2014.

Dańda A. (2008), System partyjny Wielkiej Brytanii, w: Systemy partyjne państw Unii Europejskiej, pod red. Beaty Kosowskiej-Gąstoł, Kraków.

Das Program der AfD zur Europawahl, https://www.alternativefuer.de/wp-content/uploads/2014/ 05/AfD_Europawahl_Programm_web.pdf, 21.05.2014.

Decker F., Neu V. (red.) (2007), Handbuch der deutschen Parteien, Wiesbaden.

Drieschner F. (2013), Bloß gegen den Euro, „Die Zeit”, 7.03.2013.

Er will was sehen für sein Geld (2013), „Die Zeit”, 4.07.2013.

Gmurczyk J., Wyspa eurosceptyków, www.instytutobywatelski.pl, 17.08.2014.

Göbel H., Merkels Verdrusswort, „Frankfurter Allgemeine Zeitung”, 18.01.2011, www.faz.net/ aktuell/wirtschaft/alterantivlos-merkels-verdrusswort-1574350.html, 12.05.2014.

Haste mal ne Mark? (2013), „Der Spiegel”, 8.04.2013.

Jahn J. (2013), Den Euro durch Lügen retten, „Frankfurter Allgemeine Zeitung”, 18.07.2013.

Janicka I. (2013), Nowa polityka energetyczna drugiego gabinetu Angeli Merkel, w: Niemiecka scena polityczna 2009-2013. Aktorzy, zagadnienia i wyzwania, red. A. Kruk, M. Sus, Wrocław.

Janik M. (2013), Wyborczy kabaret, 28 lipca 2013, „Wprost”.

Jendroszczyk P. (2014), Niemieccy eurosceptycy nie do powstrzymania, „Rzeczpospolita”, 2.09.2014.

Linke und AfD gegen Merkeles Euro-Politik (2013), ,Frankfurter Allgemeine Zeitung”, 18.07.2013.

Niedermayer O. (2008), Das fluide Fünfparteiensystem nach der Bundestagswahl 2005, w: Die Parteien nach der Bundestagswahl 2005, red. O Niedermayer, Wiesbaden.

Plöchinger S., Durchbruch für die digitalen Wutbürger, „Süddeutsche Zeitung online”, 18.09.2011, http://www.sueddeutsche.de/digital/piratenpartei-im-berliner-abgeordne-tenhaus-durchbruch-fuer-die-digitalen-wutbuerger-1,1145415, 4.09.2013. 
Politische Leitlinien der Alternative für Deutschland, https://www.alternativefuer.de/wp-content/ uploads/2014/05/Politische-Leitlinien-der-Alternative-f\%C3\%BCr-Deutschland-Mai-2014-Version-f\%C3\%BCr-den-Druck.pdf, 20.05.2014.

Priester K. (2014), Rechtspopulismus im Aufwind, „Neue Gesellschaft Frankfurter Hefte”, nr 4. Rybarczyk M. (2014), Zapraszam do wyjścia, „Newsweek”, 5.05.2014.

Satzung der Alternative für Deutschland, alternativefuer.de/wp-content/uploads/2014/03/Bundessatzung-Parteibeschluss.pdf, 13.05.2014.

Scheuermann Ch. (2014a), Hirn gegen Herz, „Der Spiegel”, 21.05.2014.

Scheuermann Ch. (2014b) Britain's Political Poltergeist: Cameron Succumbs to Growing Europhobia, „Spiegel Online”, http://www.spiegel.de/international/europe/cameron-succumbs-to-growing-europhobia-in-the-uk-a-876104.html, 23.08.2014.

Sulik R. (2012), Deutschland ruiniert sich, „Die Zeit”, 19.08.2012, www.zeit.de/2012/33/ Euro-Rettung-Zahlung-Deutschland, 10.05.2014.

Taking down Nigel Farage, „The Economist”, http://www.economist.com/news/britain/21602207-tories-have-kept-their-cool-against-uk-independence-party-now-they-must-attack-it-taking, 23.08.2014.

To będzie już inna Unia Europejska. Wysokie zwycięstwa eurosceptyków w Europie, niezależna.pl, http://niezalezna.pl/55666-bedzie-juz-inna-unia-europejska-wysokie-zwyciestwa-eurosceptykow-w-europie, 24.08.2014.

What We Stand For, www.ukip.org/issues, 17.08.2014.

White M., Britain, proud home of Euroscepticism, www.theguardian.com, 17.08.2014.

Woyke W. (2013), Bundestagswahl 2013, Infoaktuell. Informationen zur politischen Bildung, Bonn.

Wójcik Ł. (2013), Twardy keks do zgryzienia, „Polityka”, 15.01.2013.

\section{Streszczenie}

Tematyką artykułu jest narastające dynamicznie zjawisko eurosceptycyzmu, reprezentowane przez partie polityczne dwóch najważniejszych członków UE: Republiki Federalnej Niemiec i Wielkiej Brytanii. Celem pracy jest pokazanie genezy, analiza założeń, struktur i programów dwóch partii eurosceptycznych - AfD oraz UKIP, działających ofensywnie zarówno na krajowej, jak i europejskiej scenie politycznej. Ukazano je na tle otoczenia politycznego, analizując jego systemy partyjne i czynniki mające wpływ na ewolucję „,buntu obywateli” wobec systemu wspólnotowego. Autor próbuje odpowiedzieć na pytania, czy omówione partie są w stanie wpłynąć w sposób bezpośredni na dotychczasową politykę europejską tych dwóch państw i zmienić perspektywę UE na najbliższe lata.

Słowa kluczowe: eurosceptycyzm, AfD, UKIP, kryzys UE, partie eurosceptyczne

\section{Offensive of Euro-sceptic parties in the UK and Germany}

\section{Summary}

The subject of the paper is the dynamically expanding phenomenon of euroscepticism, which is represented by the political parties of the two most important EU members: the Federal Republic of Germany and the UK. The aim of the study is to show the origins and analyse the as- 
sumptions, structures and programmes of these two eurosceptic parties - AfD and UKIP, which are highly active both on their respective national stages and on the European political arena. They are shown against the background of their political environment, analysing the party systems and the factors affecting the evolution of the 'revolt of citizens' against the Community system. The author tries to answer the questions of whether these two parties are able to influence the current European policy of their respective countries directly and change the EU perspective in the next few years.

Key words: euroscepticism, AfD, UKIP, EU crisis, eurosceptic parties 